\title{
FOREIGN LANGUAGE TEACHING IN THE SYSTEM OF DISTANCE EDUCATION
}

Nowadays, new computer-based technologies have a significant impact on education. The roles of teachers and students are changing increasing the ratio of self-studying, and «education for life» is shifting to «lifelong education». Already, computerbased technologies are being actively incorporated into the educational process, specifically into teaching foreign languages, in many educational institutions.

In this paper, the conditions of distance learning of a foreign language are considered. The problems of effective organization of language learning in the conditions of the pandemic and forced isolation are outlined. In the paper, we draw attention to the unique features of a foreign language acquisition according to its specific linguistic and communicative competences. The analyses of the existing distance learning system facilities for language learning provided an opportunity to consider different approaches to the educational materials and modern technical means for professional language training. The main issues of providing opportunities for the practical teaching of languages using the types of synchronous or asynchronous interaction in conditions of distance learning are identified and the development of communicative competences supported by computer-based technologies is analysed. A blend between network hypertext opportunities and the system of teaching methods is regarded as the most beneficial for language acquisition.

The paper considers some distance language learning advantages provided by the grater possibilities for independent work, a quick search for information, effective communicative tools, use of multimedia, which increases students'motivation and willingness to participate in different class activities.

The specifics of creating a specially tailored educational course for foreign languages studying are analysed and the possibilities of getting professional language education remotely are stressed. The paper outlines the necessity of the state's attention drawn to the question of reliable and effective foreign language distance course organization.

Key words: computer-based technologies, foreign language, foreign language acquisition, learning technologies, distance education, distance learning system, online learning environment, professional training.

The latest changes in the society have proved the inevitability of advent of the era of information, characterized by an unprecedented, constantly accelerating growth of data submission. Information and communication technologies are an integral part of modern society. More and more data is being digitalized and about $90 \%$ of all existing information is now stored in digital format in computer networks. The development of fundamentally new opportunities for acquiring information in constantly growing numbers, and of new communication methods have a significant impact on education.

One of the tasks of the modern linguistic education system is the provision of open access to the life-long education for every person, taking into account their interests, abilities and needs. Currently, in the era of the rapid development of computer-based technologies, and due to the recent spread of the pandemic, the use of distance form of education for language learning is becoming increasingly popular [2; 5]. Some scientists and university professors believe that the transition to a computer-based education system in the language studying will significantly increase the effectiveness of specialists' training within higher professional education. In their opinion, the results of distance learning are not inferior to or even superior to the knowledge received by students in traditional classes.

The concept of distance education as an important part of gaining information, knowledge and skills in the post-industrial society was laid by Z. Brzezinski, D. Bell, O. Toffler. Considering social development as a change of stages, supporters of the information society theory associate its development with the dominance of the computer-base technologies following the second language acquisition. Distance learning for teaching foreign languages has attracted the scientists' attention [3] primarily in response to the demands for greater scheduling flexibility unconstrained by time and place [1].

During the last decades, numerous studies dedicated to the phenomenon of distance learning of foreign languages have been made. The significant fundamental research of Z. Abrams, J. Belz, R. Hampel, and M. Hauck, S. Thorne, R. Blake, S. Payne, M. Warschauer and others described the latest changes in the computer-assisted technologies for language learning in the educational process.

Nowadays, the issues of distance learning for various socio-economic and health reasons are becoming increasingly important. People need a more flexible system of higher education that allows them to get basic or additional education without interrupting their main activities, as well as providing equal opportunities for all. At the same time, the necessity for creating conditions for lifelong education and training, increasing the adjustment time to the market demands becomes increasingly more obvious.

The task of learning process effective organization for successful language learning in the conditions of practically independent educational activities caused by the pandemic and forces isolation is complicated. The special features of a foreign language learning are that the goal of training is not so much gaining knowledge about the subject itself (linguistic competence), but the development of certain skills and abilities of various communicative activities (communicative competence). These include the ability to comprehend a foreign-language text, to understand the interlocutor, and to express your thoughts in oral or written form. Due to the communicative specifics of a foreign 
language subject, it is impossible to employ the distance education used for theoretical disciplines of lecture-type to teaching languages. In this regard, searching for optimal distance learning methods and techniques for a foreign language teaching is a complicated issue.

The aim of the article. The paper aims at the general analyses of the modern state of distance learning system facilities for language acquisition and considers fundamental approaches to the selection of educational content suitable for professional language training.

The transformation of the approach to language acquisition was made possible on the basis of computer-based technologies development, which is the key to modernizing education. In a number of countries, computer-based technologies are considered as a key component in improving the quality of education through changes in curricula, teaching new practical skills and the varying the disciplines' content. Firstly, computer-based communication technologies have been mainly used to facilitate access to education for different social groups, to enhance the self-studying process, and to meet the special needs of different categories of students [1].

The modern trend towards computerization in our society also encompasses the education system, which mostly happens as an initiative of educational institutions, professional pedagogic communities and individual teachers and only later followed as different types of directive documents [4]. However, it is absolutely obvious that there are no common policies towards the computer-based technologies implementation in the educational process as a generally accepted long-term national strategy. Even the latest pandemic has not changed much in a slow pace of the state establishments.

Undoubtedly, in the transitional period, different socio-economic problems are exposed, including educational issues. Modern technologies are not able to eliminate most of these difficulties. Nevertheless, they are highly dependent on the range of computer communication used in the educational process. Otherwise, society is threatened with chronic lag and inconsistency in solving the problems posed before us.

The same issues are also relevant for more specific level of linguistic education, as the same problems remain in this sphere. Based on its ontological nature, computer-based technologies provide rich opportunities for the practical teaching of languages. Among them, there are different types of teacher-student(s) and student-student interaction in conditions of distance learning as well as the possibilities of communication with native speakers located anywhere in the world in a synchronous or asynchronous mode. Foreign language interlocutors can be individuals, a small group, or even a global international conference involving hundreds and thousands of people all over the world.

Linguistic education has its own specific tasks in line with general educational issues. The development of communicative competence is one of them along with sociocultural and linguodidactics acquisition. Computer technologies assisted in the appearance of new directions like computational linguodidactics. The concept of distance learning of a foreign language has become widely used along with the traditional face-to-face learning methods.

There are a number of advantages and opportunities in the use of computer technologies and computer-assisted learning. The most evident ones are the learners' motivation increase, tasks interactivity, and easy establishment of teacher-student(s) and student-students interaction.

Computers are undoubtedly attractive tools for the younger generation that has grown up and most of them belong to the so-called Net Generation. They expect the teachers to use widely this technology in teaching. Exercises are boring in the classroom but in a form of interactive or role-playing games they motivate students, the tests with immediate answers stimulate students to work with the language, but at the same time, they do it with pleasure and interest.

The effectiveness of teaching increases due to the opportunity provided by the computer-based technologies, which influences its organization and reduces routine operations, helps the teachers use their time creatively and more productively. The idea of combining possibilities of computer-based technologies and educational content as a package of services and content, created by a professional teacher, is supported by Professor of the University of New York State Carla Meskill: «Media and technologies can be tremendously useful tools for extending the ways both learners and teachers consider language learning enterprises and for generating fresh and stimulating perspectives. However, it is the position of this text that such new perspectives are not simply born out of the physical presence of wires and electrodes. On the contrary, it is our forever flexible and evolving beliefs about how language is best taught and learned that serve as the most critical groundings to further the evolution in our thinking about, with, and through these new tools» [8].

Statistical data indicate that the computerization of the process of teaching a foreign language on a well-planned didactic basis provides a range of advantages to teacher and students, and ensures much greater flexibility and adaptability of the educational process to specific objectives and conditions. The teacher gets an opportunity to manage learning more effectively (especially for large groups), improve the quality of students' independent work, achieve the information about their progress quickly, increase the effectiveness of discussions and reduce the percentage of students unwilling to participate in various types of activities [7].

Likewise, students have demonstrated a positive attitude to distance learning and greater satisfaction with their studies, their motivation increased. The numerous survey results showed that the students enjoyed using computers for the language studying, readily participated in various types of discussions expressing their opinions not only in the classroom but also after class in different forums and discussion groups [6]. These communicative activities 
were especially attractive for those students who, due to their nature, usually avoided speaking in front of the public. The opportunity to speak without seeing the audience in front of them is a great opportunity for such students. The received feedback also revealed the students' interest in doing research projects online. They search for specific information independently employing web resources, which are a good exercise for the studied material practical application. Also, the students are attracted by the distance learning system's flexibility and autonomy, their ability to practice at a convenient time and pace, outside the limitations of classroom learning.

Computer-based technologies allow different ways of communication regardless of the location of its participants. A group of students can participate in the discussion, games and simulations, creating short stories and dialogues. They communicate with each other outside the classroom to complete specific projects, group assignments and prepare general course projects. Video conferencing technologies make it possible to include native speakers in a discussion from any part of the world, which facilitates the development of linguistic, sociolinguistic, discursive, and cross-cultural competences [5].

An effective distance learning of a foreign language should be based on a specially designed virtual language environment, including a set of electronic educational and communication tools that allow the organization of an interaction between the subjects of the educational process separated by space and time. At the same time, distance learning should provide a reliable evaluation of this process.

The study of the individual aspects of the language system leads to the fact that a living language is sometimes regarded by the learner as a number of isolated elements of mechanical grammar rules and long lists of memorised words, which should be according to set instructions [7]. Obviously, an integral approach to a foreign language learning involving the simultaneous processes of grammar and vocabulary acquisition with practical communication is the most productive.

One of the most complicated and time-consuming task for students is the development of writing skills. Sometimes it is completely ignored in distance learning, in spite of the fact that written communication is an urgent need for an adult educated person. However, teaching writing remotely should always possess a semantic meaning and be carried out within the framework of personal communication. Both the amount and the lexical rate can vary.

Special attention should be paid to the possibility of the computer-assisted knowledge control procedure development. After finishing a module or course the students should be assessed for their performance and the achieved results. The computer-based technologies could free the teacher from tedious homework and tests checking.

The advantages of computer-based foreign language distance learning are obvious. The students have an opportunity to study in any place and at a convenient time, as well as at their own pace and rhythm. The distance from the student's location to the university is not an obstacle to an effective educational process. Students can interact with the teacher individually or in groups. In addition, they have an opportunity to arrange an individual curriculum from a set of independent course modules which meets their needs. As a result, the costs of training are reduced due to more efficient use of training space, time and technical means.

However, despite the undoubted advantages of the latest computer technologies, distance education should definitely rely on the developed system of methods for teaching a foreign language. It should be noted that within the framework of distance learning, it is beneficial to use computer technologies for real-time activities such as lessons, tutorials, discussion clubs, and conferences etc. Learning interaction with other learners even organized in a virtual classroom establishes mutual friendly relations, builds team spirit and increases students' self-esteem. This is especially important due to the specifics of foreign language learning.

Due to the wide use of computer-based technologies application, the emphasis is being shifted from teaching to learning. The student becomes the central figure of the educational process primary responsible for his/her learning progress. The teacher ceases to be a source of knowledge; with distance learning, this role is transferred to an artificially created educational computer programs. The teacher is free from controlling functions and becomes a tutor for students whose main function is to organize and manage the educational process.

Conclusions. Undoubtedly, the distance learning of foreign languages is a step forward. However, it demands creating a special educational course by a university that would permit to benefit from its obvious positive sides and to cope with some of the listed difficulties. Moreover, from a technical point of view, there are no obstacles to distance learning from educational institutions. The necessary infrastructure is already here. With the effective organization and widespread computer network development, despite the high costs at the initial stages, the economy and effectiveness of training can be beneficial for all its participants.

The recent events taking place in the society require changes in the education system shifting its development according to the needs of an individual learner. At the same time, the possibilities of getting education remotely due to the achievement of a higher level of accessibility should be accompanied by an increase in the quality of teaching and learning. The question of the organization of reliable and effective foreign language acquisition still requires a great amount of attention from the pedagogical and scientific community.

\section{Bibliography:}

1. Belz J. A., Thorne S. L. Internet-mediated Intercultural Foreign Language Education. Annual Volume of the American Association of University Supervisors and Coordinators. 2006. Pp. 12-25.

2. Blake R. Distance Learning for Second and Foreign Language Teaching. Encyclopedia of Language and Education. 2008. URL: https://doi.org/10.1007/978-0-387-30424-3_111 (Last accessed: 23.12.2020). 
3. Blake R., Delforge A. M. Online language learning: The case of Spanish without walls. Spanish Second Language Acquisition: The Art of Teaching Spanish. 2006. Pp. 127-147.

4. Про затвердження Положення про дистанційне навчання : Наказ від 10.10.2020 p. № z0703-13. URL: https://zakon.rada.gov.ua/laws/show/z0703-13\#Tехt (дата звернення: 23.12.2020).

5. Halász G., Michel A. Key Competences in Europe: interpretation, policy formulation and implementation. European Journal of Education. 2011. Vol. 46. Pp. 289-306. URL: https://doi.org/10.1111/j.1465-3435.2011.01491.x (Last accessed: 23.12.2020).

6. Havrylenko K. M. Distance education learning potential in traditional system of professional education. Innovative Pedagogy. Periodical scientific journal of the Black Sea Research Institute of Economy and Innovation. 2019. Vol. 17, Part. 1. Pp. 39-42.

7. Кухаренко В. М., Бондаренко В. В. Екстрене дистанційне навчання в Україні : монографія. Харків : Вид-во КП «Міська друкарня», 2020. 409 c.

8. Meskill C. Teaching and Learning in Real Time: Media, Technology, and Language Acquisition. Houston : TX: Athelstan, 2002. 220 p. P 1.

\section{References:}

1. Belz J. A., Thorne S. L. (2006) Internet-mediated Intercultural Foreign Language Education. Annual Volume of the American Association of University Supervisors and Coordinators. P. 12-25.

2. Blake R. (2008) Distance Learning for Second and Foreign Language Teaching. Encyclopedia of Language and Education. URL: https://doi.org/10.1007/978-0-387-30424-3 111 (Last accessed: 23.12.2020).

3. Blake R., Delforge, A. M. (2006). Online language learning: The case of Spanish without walls. Spanish Second Language Acquisition: The Art of Teaching Spanish. P. 127-147.

4. Polozhennja pro dystancijne navchannja [Distance education regulation]: Regulation of 16.10.2020 No. 13. URL: https://zakon.rada.gov.ua/laws/show/z0703-13\#Text (Last accessed: 23.12.2020) [in Ukrainian]

5. Halász G., Michel A. (2011). Key Competences in Europe: interpretation, policy formulation and implementation. European Journal of Education. Vol. 46. P. 289-306. URL: https://doi.org/10.1111/j.1465-3435.2011.01491.x (Last accessed: 23.12.2020).

6. Havrylenko K. M. (2019). Distance education learning potential in traditional system of professional education. Innovative Pedagogy. Periodical scientific journal of the Black Sea Research Institute of Economy and Innovation. Vol. 17, Part. 1. P. $39-42$.

7. Kukharenko V. M, Bondarenko V. V. (2020). Ekstrene dystancijne navchannja v Ukrajini. [Emergency distance learning in Ukraine]. Kharkiv: Mis'ka drukarnya, 409 p. [in Ukrainian]

8. Meskill C. (2002). Teaching and Learning in Real Time: Media, Technology, and Language Acquisition. Houston: TX: Athelstan, 220 p. P. 1.

\section{Гавриленко К. М. Навчання іноземних мов у системі дистанційної освіти}

У наш час нові комп'ютерні технології мають значний вплив на освіту. Ролі викладачів та студентів змінюються, збільшуючи співвідношення самонавчання, а «освіта на все життя» змінюється на «освіту протягом усього життя». Уже зараз комп'ютерні технологї активно залучаються до освітнього процесу, зокрема у викладанні іноземних мов, у багатьох навчальних закладах.

У статті розглядаються умови дистаниійного навчання іноземної мови та окреслюються проблеми ефективної організації вивчення мови, придатні для сучасних умов пандемії та вимушеної ізоляції. У статті ми звертаємо увагу на особливості засвоєння іноземних мов відповідно до їх специифічних мовних та комунікативних компетенцій. Аналіз наявних засобів дистанційного навчання у иій галузі дав можливість розглянути різні підходи до підбору навчальних матеріалів та сучасних технічних засобів для професійної мовної підготовки. Визначено основні питання забезпечення можливостей практичного викладання мов із використанням синхронної або асинхронної взаємодії в умовах дистанційного навчання та проаналізовано розвиток комунікативних компетентностей, які забезпечуються комп'ютерними технологіями. Поєднання можливостей мережевого гіпертексту та сучасної системи методів навчання розглядається як найбільш придатна комбінація для вдалого засвоєння мовленнєвих навичок.

У статті розглядаються такі переваги дистанційного вивчення мови, як забезпечення більш широких можливостей для самостійної роботи, швидкий пошук інформації, ефективні комунікативні засоби, використання мультимедіа, щчо підвищує мотивацію та бажання студентів брати участь у навчальній діяльності.

Проаналізовано особливості створення спеціально розробленого навчального курсу для вивчення іноземних мов та наголошено на можливостях дистанційного отримання професійної мовної освіти. У статті висвітлюється необхідність державної підтримки питання надійної та ефективної організації дистанційного вивчення іноземних мов.

Ключові слова: комп'ютерні технології, іноземна мова, іншомовні компетениії, технології навчання, дистанційна освіта, система дистаниійного навчання, професійне навчання. 